\title{
Evaluation of Serum Biomarkers (FGF-2, HGF, MIF and PTN) in Patients With Testicular Germ Cell Cancer
}

\author{
STEFAN HAUSER $^{1 *}$, ANNETTE KAMINSKI ${ }^{1 *}$, ISABELLA SYRING ${ }^{1}$, STEFAN HOLDENRIEDER $^{2}$, \\ KLAUS-PETER DIECKMANN ${ }^{3}$, STEFAN C. MULLER ${ }^{1}$ and JORG ELLINGER ${ }^{1}$ \\ ${ }^{1}$ Universitätsklinikum Bonn, Klinik und Poliklinik für Urologie und Kinderurologie, Bonn, Germany; \\ ${ }^{2}$ Universitätsklinikum Bonn, Institut für Klinische Chemie und Klinische Pharmakologie, Bonn, Germany; \\ ${ }^{3}$ Albertinen Krankenhaus, Klinik für Urologie, Hamburg, Germany
}

\begin{abstract}
Background/Aim: FGF-2, HGF, MIF and PTN have been suggested as biomarkers for testicular germ cell cancer patients in earlier studies. Our study was designed to validate these potential novel tumor markers. Materials and Methods: Serum FGF-2, HGF, MIF and PTN levels were analysed using an ELISA technique in a screening cohort of 20 testicular germ cell cancer patients and 10 healthy men. MIF levels were measured in a validation cohort of 84 patients with testicular cancer, 24 with non-malignant testicular tumors and 64 healthy men. Results: Serum FGF-2, HGF and PTN levels did not differ in cancer patients and healthy males within the screening cohort, whereas MIF was significantly increased among cancer patients. Within the validation cohort, a modest but insignificant increase of serum MIF was observed in TGCT patients compared to healthy men. MIF levels were not correlated with adverse clinical-pathological parameters. Conclusion: FGF-2, HGF, MIF and PTN are not suitable as non-invasive biomarkers for testicular germ cell cancer patients.
\end{abstract}

Testicular germ cell cancer (TGCT) is the most common malignancy in young men. The incidence of TGCT is still rising in many western countries, while mortality rates remain low. The successful treatment of patients with even advanced metastatic TGCT is mainly due to the effective multimodal therapy (polychemotherapy, radiotherapy and surgery) (1). The

This article is freely accessible online.

*These Authors contributed equally to this study.

Correspondence to: PD Dr. med. Stefan Hauser, Universitätsklinikum Bonn, Klinik und Poliklinik für Urologie und Kinderurologie, SigmundFreud-Strasse 25, 53105 Bonn, Germany. Tel: +49 22828714184, Fax: +4922828714185, e-mail: stefan.hauser@ukbonn.de

Key Words: Testicular cancer, biomarker, serum, MIF, FGF, HGF, PTN, ELISA, diagnosis. serum tumor markers alpha-fetoprotein (AFP) and human chorionic gonadotropin (hCG) are used for diagnosis, risk stratification, treatment monitoring, and surveillance (2). However, both biomarkers lack high sensitivity, especially in early tumor stages and seminoma TGCT patients. It is estimated that about $50 \%$ of TGCT patients have normally ranged tumor markers (3). Thus, novel non-invasive tumor markers with improved sensitivity could help improve the clinical management of TGCT patients.

A variety of potential TGCT biomarkers including circulating nucleic acids [e.g. microRNA $(4,5)$, DNA methylation (6), DNA concentration (7)] and serum proteins [e.g. Fas ligand (8), TNFRSF8 (9)] have been evaluated, but none of them have yet been applied in daily routine due to the lack of validation studies and the small case numbers (10). Aigner et al. reported in 2003 an increase in serum FGF-2 (fibroblast growth factor2) and PTN (pleiotrophin) levels in TGCT patients $(n=22)$ compared to healthy individuals $(n=21)(11)$; both proteins are involved in tumor angiogenesis. Serum PTN [e.g. colorectal (12), lung (13), pancreatic (12)] and FGF-2 [e.g. colorectal (14), ovarian (15), lung (16)] levels were also increased in other cancer patients, indicating the possible diagnostic role of these proteins. In a recent study, we investigated the circulating levels of various cytokines in patients with human malignancies including TGCT patients. Among these, MIF (macrophage migration inhibitory factor) and HGF (hepatocyte growth factor) were significantly increased in TGCT patients compared to control subjects. In order to validate the findings of these earlier studies, we investigated serum biomarker levels in an enlarged cohort of patients with malignant and benign testicular disease, as well as in healthy men.

\section{Materials and Methods}

Sample collection. First, we investigated the serum concentration of FGF-2, HGF, MIF and PTN in a screening cohort of 20 testicular germ cell cancer patients (10 seminoma and 10 non-seminoma patients) and 10 healthy subjects; see Table I for clinicalpathological parameters. The validation of MIF expression levels 
was then performed in 108 patients undergoing inguinal exploration suspicious for testicular cancer; among these, 84 patients had malignant testicular germ cell cancer (seminoma $n=48$, nonseminoma $\mathrm{n}=35$ ) and 24 had non-malignant diseases (histological diagnosis: intratubular germ cell neoplasia $n=1$; epidermoid cyst $\mathrm{n}=6$; leydig cell tumor $\mathrm{n}=6$; sertoli cell tumor $\mathrm{n}=1$; mature teratoma $\mathrm{n}=2$; adenomatoid tumor $\mathrm{n}=2$; testicular infarction $\mathrm{n}=1$; infection $\mathrm{n}=1$; stromal spindle cell tumor $\mathrm{n}=1$; scar tissue $\mathrm{n}=1$; fibroma $\mathrm{n}=1$; fibrosis $\mathrm{n}=1$ ). We also studied an age-matched control cohort that consisted of 64 healthy male individuals. The detailed clinicopathological parameters are provided in Table II.

The collection of serum samples was performed according to local standard operating procedures within the framework of the Biobank initiative at the CIO Köln/Bonn. In brief, venous blood was collected in Serum S-Monovette Gel tubes with clotting activator (Sarstedt, Nümbrecht, Germany) prior to surgery. Serum was centrifuged after clotting for $10 \mathrm{~min}$ at $2500 \mathrm{~g}$; the separated serum samples were stored in cryotubes at $-80^{\circ} \mathrm{C}$ until use. Sample collection was performed between 1997 and 2014. Written informed consent was obtained from each individual and the study was approved by the local ethic committee (approval number: 162/14). The study conformed with The Code of Ethics of The World Medical Association ("Declaration of Helsinki”).

ELISA. The serum levels of FGF-2 (Quantikine FGF Immunoassay; R\&D Systems, Minneapolis, MN, USA), HGF (Quantikine HGF Immunoassay; R\&D Systems), MIF (Quantikine MIF Immunoassay; R\&D Systems) and PTN (ELISA Kit for Pleiotrophin; Cloud-Clone, Houston, TX, USA) were quantified using ELISA kits according to the manufacturer's recommendations. We used $50 \mu \mathrm{l}$ (MIF) or $100 \mu \mathrm{l}$ (FGF-2, HGF, PTN) of serum for the analysis; each sample was measured in duplicate. A standard curve was constructed using the supplied standard to determine serum protein levels. The optical density of each well was detected at $450 \mathrm{~nm}$ on an SLT-reader (Tecan, Crailsheim, Germany).

Statistical analysis. The Mann-Whitney $U$-test and the KruskalWallis-test were used to determine differences between cancer patients and controls, and to associate MIF expression with clinicalpathological parameters. The Pearson test was used to correlate AFP/HCG with MIF levels. The diagnostic sensitivity and specificity of the biomarkers was determined using receiver operator curve (ROC) analyses. Statistical significance was concluded at $p<0.05$; statistical analyses were performed using SPSS Statistics v22 (IBM, Chicago, IL, USA).

\section{Results}

Screening cohort. The serum levels of FGF-2, HGF, MIF and PTN were determined in a screening cohort of 10 seminoma and 10 non-seminoma patients, as well as 10 healthy male individuals (Figure 1). FGF-2, HGF and MIF were detected in all study patients. PTN was not detected in non-seminoma patients and only in one individual of the control group, whereas it was detectable in all seminoma patients. The serum levels of MIF were significantly increased in TGCT compared to healthy individuals (mean $7.47 \mathrm{ng} / \mathrm{ml} v s .3 .17$ $\mathrm{ng} / \mathrm{ml} ; p=0.005)$, whereas FGF-2 $(p=0.965)$ and HGF $(p=0.965)$ were similar in both cohorts. Mean serum levels of all markers were similar in non-seminoma and seminoma TGCT patients (FGF-2 $p=0.307$; HGF $p=0.880$; MIF $p=0.762)$. MIF levels were higher in seminoma $(p=0.013)$ and non-seminoma $(p=0.019)$ patients compared to controls (Figure 1).

Validation cohort. In order to validate the potential of MIF as a novel TGCT biomarker, we investigated its serum concentration in a larger cohort which included 84 patients with testicular cancer (seminoma $n=48$, non-seminoma $n=35$ ), 64 healthy male individuals and 24 patients with nonmalignant testicular disease. The mean level of MIF was 5.05 $\mathrm{ng} / \mathrm{ml}$ in TGCT patients, $4.03 \mathrm{ng} / \mathrm{ml}$ in healthy men and 5.83 $\mathrm{ng} / \mathrm{ml}$ in patients with benign testicular disease. Thus, MIF levels in serum were neither different in cancer patients and healthy male $(p=0.071)$ nor in patients with benign testicular disease $(p=0.221)$. However, MIF was increased in patients with benign testicular disease compared to healthy male $(p=0.019)$. MIF levels were similar in seminoma and nonseminoma TGCT ( $p=0.414)$. Thus, serum MIF levels failed as a diagnostic biomarker: the area under curve was 0.541 (95\% confidence interval 0.454-0.627) for cancer patients $v s$. healthy male and benign patients, and 0.587 (0.495-0.679) for cancer patients $v s$. healthy males, respectively (Figure 2). We also investigated whether MIF levels were correlated with clinical-pathological parameters: advanced pathological stage (pT1 vs. pT3 $p=0.045$; pT2 vs. pT3 $p=0.039$ ) was associated with MIF levels (mean: pT1 $5.04 \mathrm{ng} / \mathrm{ml}$, pT2 $4.54 \mathrm{ng} / \mathrm{ml}$, pT3 $7.62 \mathrm{ng} / \mathrm{ml}$ ). Clinical tumor stage, IGCCCG stage and serum tumor markers (AFP, HCG) were not correlated with serum MIF concentrations (all $p>0.1$ ).

\section{Discussion}

Novel non-invasive tumor markers with improved sensitivity compared to the classical markers AFP and hCG could improve the clinical management of TGCT patients. In former studies, several proteins including FGF-2 (fibroblast growth factor-2) (11), PTN (pleiotrophin) (11), MIF (macrophage migration inhibitory factor; Stefan Holdenrieder et al., unpublished data) and HFG (hepatocyte growth factor; Stefan Holdenrieder et al., unpublished data) markers have been investigated in small TGCT cohorts with promising results. However, all candidate markers still require validation in independent cohorts and therefore we determined the serum levels of these markers in an enlarged cohort of patients with TGCT, non-malignant testicular disease and healthy men.

We first determined FGF-2, HGF, MIF and PTN levels in a screening cohort. Surprisingly, PTN was not detected in most patients, and HFG and FGF-2 were not differentially expressed in TGCT patients and healthy men. Thus, our study does not confirm a role of these proteins for diagnostic 
Table I. Clinical-pathological parameters of patients investigated in the screening experiments.

\begin{tabular}{|c|c|c|c|c|}
\hline & $\begin{array}{l}\text { TGCT } \\
(\mathrm{n}=20)\end{array}$ & $\begin{array}{l}\text { Seminoma } \\
\quad(n=10)\end{array}$ & $\begin{array}{l}\text { Non-seminoma } \\
\quad(\mathrm{n}=10)\end{array}$ & $\begin{array}{l}\text { Healthy } \\
(\mathrm{n}=10)\end{array}$ \\
\hline \multicolumn{5}{|l|}{ Age } \\
\hline mean & 40.0 & 46.7 & 33.3 & 32.3 \\
\hline $\min -\max$ & $18-76$ & $32-76$ & $18-57$ & $23-42$ \\
\hline \multicolumn{5}{|l|}{ pT-stage } \\
\hline pT1 & $12(60 \%)$ & $5(50 \%)$ & $7(70 \%)$ & n.a. \\
\hline pT2 & $6(30 \%)$ & $4(40 \%)$ & $2(20 \%)$ & n.a. \\
\hline pT3 & $2(10 \%)$ & $1(10 \%)$ & $1(10.0 \%)$ & n.a. \\
\hline \multicolumn{5}{|c|}{ Clinical stage (Lugano) } \\
\hline Stage 1 & $15(75 \%)$ & $8(80 \%)$ & $7(70 \%)$ & n.a. \\
\hline Stage 2 & $4(20 \%)$ & $2(20 \%)$ & $2(20 \%)$ & n.a. \\
\hline Stage 3 & $1(5 \%)$ & $0(0 \%)$ & $1(10 \%)$ & n.a. \\
\hline \multicolumn{5}{|c|}{ Tumor marker } \\
\hline AFP & $3(15 \%)$ & $0(0 \%)$ & $3(30 \%)$ & n.d. \\
\hline HCG & $10(50 \%)$ & $4(40 \%)$ & $6(60 \%)$ & n.d. \\
\hline Missing & $0(0 \%)$ & $0(0 \%)$ & $0(0 \%)$ & $10(100 \%)$ \\
\hline
\end{tabular}

TGCT: Testicular germ cell tumor; n.a.: not applicable; n.d.: not done.

Table II. Clinical-pathological parameters of patients investigated in the validation experiment.

\begin{tabular}{|c|c|c|c|c|c|}
\hline & $\begin{array}{l}\text { TGCT } \\
(\mathrm{n}=84)\end{array}$ & $\begin{array}{l}\text { Seminoma } \\
\quad(\mathrm{n}=48)\end{array}$ & $\begin{array}{l}\text { Non-seminoma } \\
\quad(\mathrm{n}=35)\end{array}$ & $\begin{array}{c}\text { Healthy } \\
(\mathrm{n}=64)\end{array}$ & $\begin{array}{l}\text { Benign } \\
(\mathrm{n}=24)\end{array}$ \\
\hline \multicolumn{6}{|l|}{ Age } \\
\hline Mean & 34.9 & 38.3 & 30.1 & 31.6 & 36.9 \\
\hline Min-max & $14-56$ & $23-56$ & $14-53$ & $19-64$ & $18-71$ \\
\hline \multicolumn{6}{|l|}{ pT-stage } \\
\hline pT1 & $59(70.2 \%)$ & $36(75.0 \%)$ & $23(65.7 \%)$ & n.a. & n.a. \\
\hline pT2 & $17(20.2 \%)$ & $7(14.6 \%)$ & $10(28.6 \%)$ & n.a. & n.a. \\
\hline pT3 & $4(4.8 \%)$ & $2(4.2 \%)$ & $2(5.7 \%)$ & n.a. & n.a. \\
\hline "burned out" & $3(3.6 \%)$ & $3(6.2 \%)$ & $0(0 \%)$ & n.a. & n.a. \\
\hline \multicolumn{6}{|l|}{ Clinical stage (Lugano) } \\
\hline Stage 1 & $54(64.3 \%)$ & $35(72.9 \%)$ & $19(54.4 \%)$ & n.a. & n.a. \\
\hline Stage 2 & $21(25.0 \%)$ & $11(22.9 \%)$ & & $10(28.6 \%)$ & n.a.n.a. \\
\hline Stage 3 & $9(10.7 \%)$ & $3(6.2 \%)$ & $6(17.1 \%)$ & n.a. & n.a. \\
\hline \multicolumn{6}{|l|}{ IGCCCG classification } \\
\hline Good prognosis & $22(28.6 \%)$ & $11(22.9 \%)$ & $11(31.4 \%)$ & n.a. & n.a. \\
\hline Intermediate prognosis & $6(7.1 \%)$ & $3(6.2 \%)$ & $3(8.6 \%)$ & n.a. & n.a. \\
\hline Poor prognosis & $2(0 \%)$ & $0(0 \%)$ & $2(5.7 \%)$ & n.a. & n.a. \\
\hline Not applicable & $54(61.9 \%)$ & $35(72.9 \%)$ & $19(54.4 \%)$ & n.a. & n.a. \\
\hline \multicolumn{6}{|l|}{ Tumor marker increase } \\
\hline AFP & $18(21.4 \%)$ & $0(0 \%)$ & $18(51.4 \%)$ & n.d. & $0(0 \%)$ \\
\hline HCG & $36(42.8 \%)$ & $14(29.2 \%)$ & $22(62.9 \%)$ & n.d. & $0(0 \%)$ \\
\hline Missing & $0(0 \%)$ & $0(0 \%)$ & $0(0 \%)$ & $64(100 \%)$ & $6(25.0 \%)$ \\
\hline
\end{tabular}

n.a.: Not applicable; n.d.: not done; IGCCCG: International Germ Cell Cancer Collaboration Group.

purposes in patients with TGCT. It should be noted that Aigner et al. used a self-constructed ELISA using a monoclonal antibody to measure PTN levels in serum (11), whereas a commercial ELISA kit from Cloud-Clone was used in this study. Similar to Aigner et al., we used the R\&D
Quantikine ELISA assay to determine FGF-2 levels, thereby limiting the bias due to different detection techniques. It should also be noted that PTN [colorectal (12), lung (13), pancreatic (12)] and FGF-2 [colorectal (14), ovarian (15), lung (16)] levels were also increased in other tumor entities, 

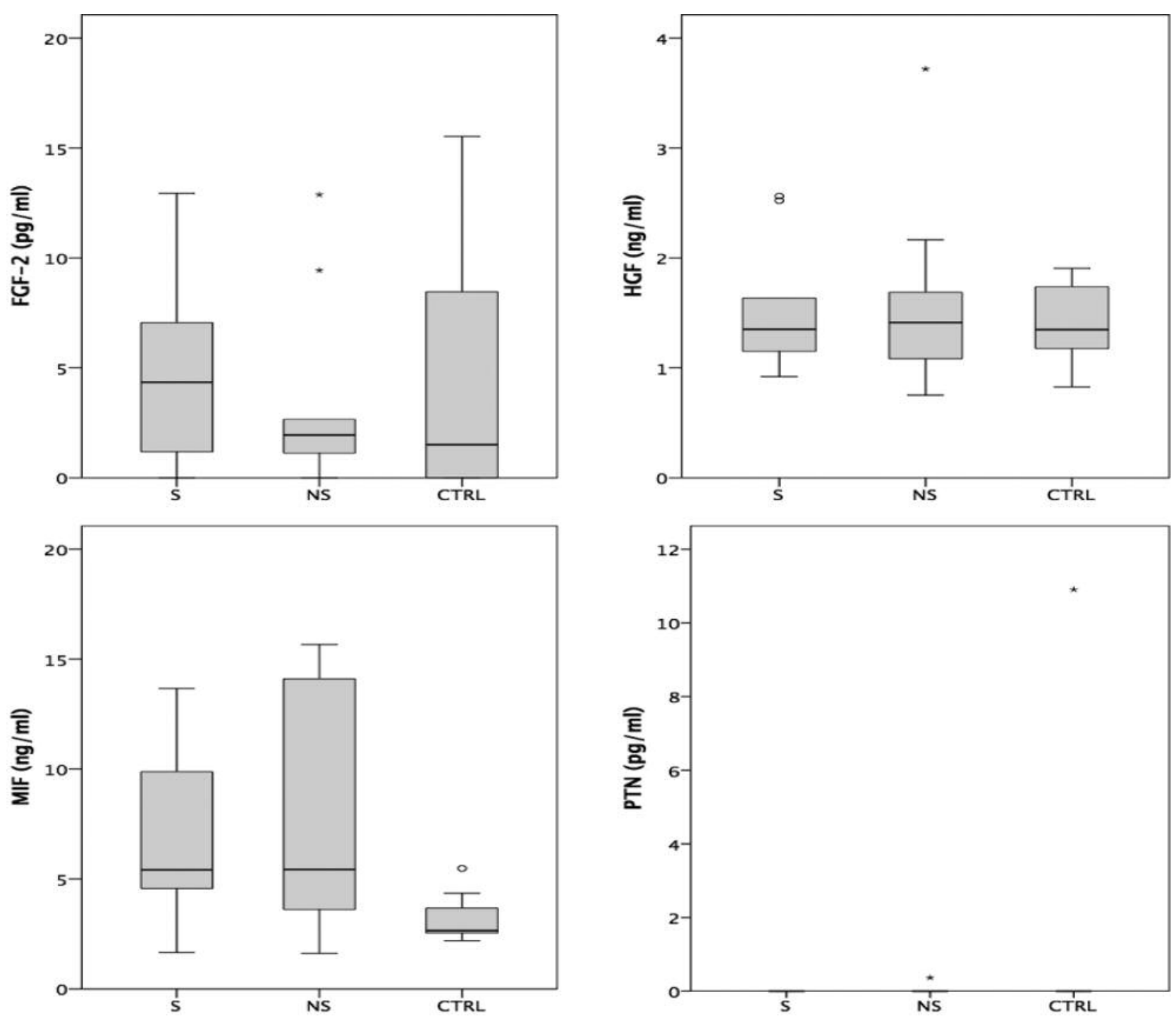

Figure 1. Screening cohort: Analysis of serum levels of FGF-2, HGF, MIF and PTN in patients with seminoma (S, $n=10)$ and non-seminoma (NS, $n=10)$ testicular germ cell cancer and healthy men (CTRL, $n=10)$. The concentration of MIF was significantly increased in cancer patients.

thus the biomarker would lack specificity and would be of limited clinical value.

MIF levels were significantly increased in TGCT patients in the screening cohort of 30 study subjects, and were thus further investigated in an independent validation group consisting of 172 subjects. However, we did not observe a difference in MIF levels in TGCT patients, men with nonmalignant testicular disease and healthy men. This finding highlights the need for validation of candidate biomarkers in independent and large-scaled cohorts which would also include relevant control subjects (i.e. non-malignant testicular tumors). Notably, we identified several expression profiling studies (17-20) showing increased MIF levels in seminoma TGCT compared to normal testis tissue using the NextBio database (21). A role for MIF as a diagnostic biomarker has been observed in other malignancies: e.g. serum MIF levels were increased in oral carcinoma (22), hepatocellular carcinoma (23), breast cancer (24), and ovarian cancer patients (25). Interestingly, a polymorphism in the $M I F$ promoter region $(-173 \mathrm{G} / \mathrm{C})$ was associated with an increased cancer risk (26).

\section{Conclusion}

Our study failed to confirm any diagnostic value for FGF-2, HGF, MIF and PTN in patients with TGCT. 

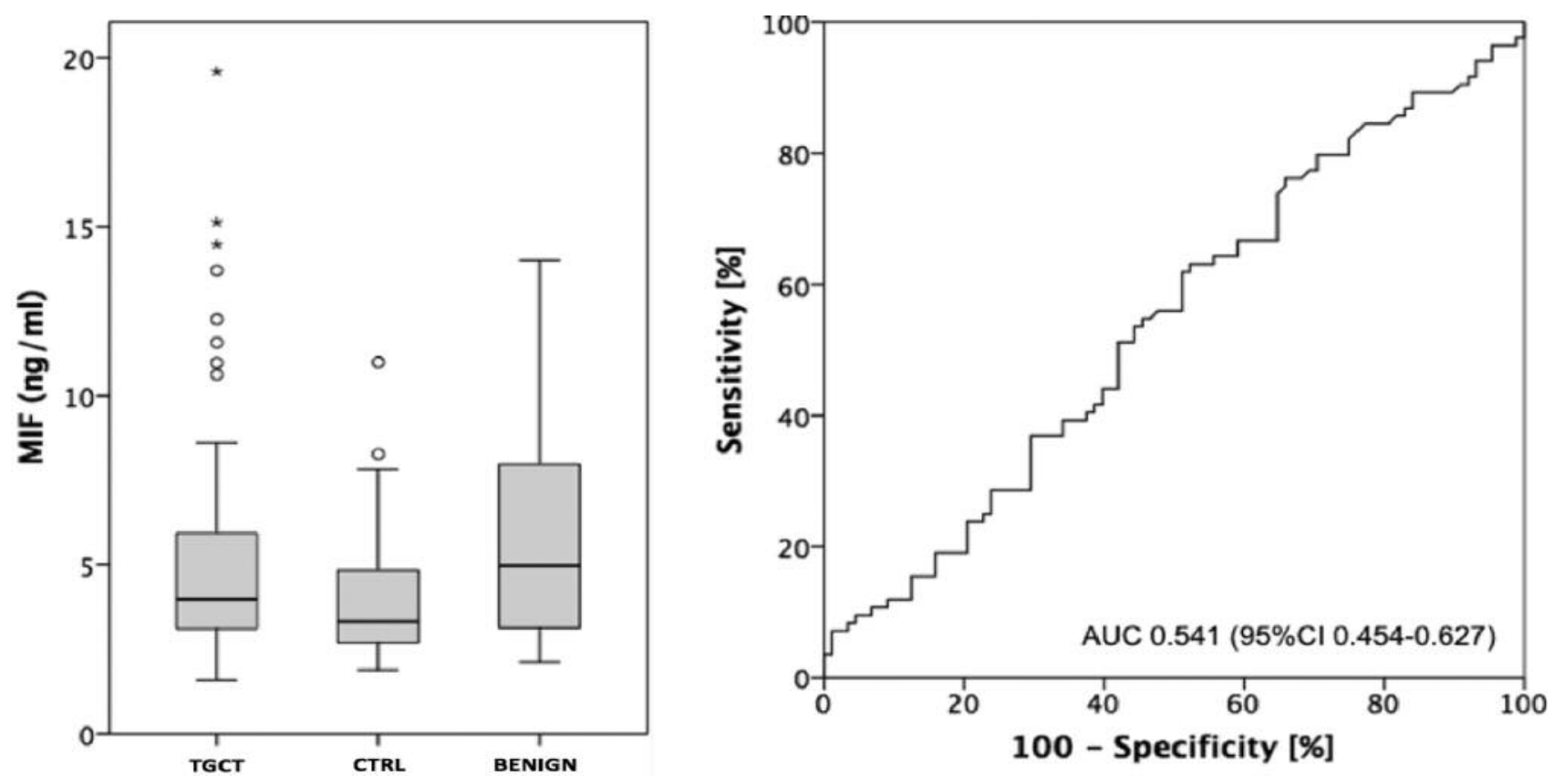

Figure 2. Validation cohort: Analysis of MIF serum levels in patients with testicular germ cell cancer (TCGT, seminoma, $n=48$; non-seminoma, $n=35)$, healthy men (CTRL, $n=64)$ and patients with various benign testicular tumors/diseases $(n=24)$. The concentration of MIF did not differ in cancer patients and control subjects. AUC: Area under curve; 95\%CI:95\% confidence interval.

\section{Conflicts of Interest}

The Authors declare that they have no competing interests regarding this study.

\section{Authors' Contributions}

All Authors made substantial contributions to the conception, design, and acquisition of data. AK performed the experiments. AK, IS and JE analysed and interpreted the data. JE and SH designed the study. AK and JE drafted the manuscript. Samples were provided by KPD and SCM. IS, SH, KPD and SCM revised the manuscript. All Authors read and approved the final manuscript.

\section{References}

1 Shanmugalingam T, Soultati A, Chowdhury S, Rudman S and Van Hemelrijck M: Global incidence and outcome of testicular cancer. Clin Epidemiol 5: 417-427, 2013. PMID: 24204171. DOI: $10.2147 /$ CLEP.S34430

2 Salem $M$ and Gilligan T: Serum tumor markers and their utilization in the management of germ-cell tumors in adult males. Expert Rev Anticancer Ther 11(1): 1-4, 2011. PMID: 21166503. DOI: $10.1586 /$ era.10.219

3 Albers P, Albrecht W, Algaba F, Bokemeyer C, Cohn-Cedermark G, Fizazi K, Horwich A and Laguna MP: Eau guidelines on testicular cancer: 2011 update. Eur Urol 60(2): 304-319, 2011. PMID: 21632173. DOI: 10.1016/j.eururo.2011.05.038
4 Syring I, Bartels J, Holdenrieder S, Kristiansen G, Muller SC and Ellinger J: Circulating serum mirna (mir-367-3p, mir-371a$3 p$, mir-372-3p and mir-373-3p) as biomarkers in patients with testicular germ cell cancer. J Urol 193(1): 331-337, 2015. PMID: 25046619. DOI: 10.1016/j.juro.2014.07.010

5 Dieckmann KP, Spiekermann M, Balks T, Flor I, Loning T, Bullerdiek $\mathrm{J}$ and Belge G: Micrornas mir-371-3 in serum as diagnostic tools in the management of testicular germ cell tumours. Br J Cancer 107(10): 1754-1760, 2012. PMID: 23059743. DOI: 10.1038/bjc.2012.469

6 Ellinger J, Albers P, Perabo FG, Muller SC, von Ruecker A and Bastian PJ: Cpg island hypermethylation of cell-free circulating serum DNA in patients with testicular cancer. J Urol 182(1): 324-329, 2009. PMID: 19447423. DOI: 10.1016/j.juro.2009. 02.106

7 Ellinger J, Wittkamp V, Albers P, Perabo FG, Mueller SC, von Ruecker A and Bastian PJ: Cell-free circulating DNA: Diagnostic value in patients with testicular germ cell cancer. J Urol 181(1): 363-371, 2009. PMID: 19010497. DOI: $10.1016 / j . j u r o .2008 .08 .118$

8 Hara S, Miyake H, Nakamura I, Arakawa S, Kamidono S and Hara I: Increased fas ligand expression in the tumor tissue and serum of patients with testicular germ cell tumors with seminomatous elements. Urology 58(3): 471-476, 2001. PMID: 11549508. DOI: 10.1016/s0090-4295(01)01172-4

9 Latza U, Foss HD, Durkop H, Eitelbach F, Dieckmann KP, Loy $\mathrm{V}$, Unger M, Pizzolo G and Stein H: Cd30 antigen in embryonal carcinoma and embryogenesis and release of the soluble molecule. Am J Pathol 146(2): 463-471, 1995. PMID: 7856755. 
10 Syring I, Mueller SC and Ellinger J: Novel tumor markers in the serum of testicular germ cell cancer patients: A review. Current Biomarker Findings 4: 133-137, 2014. DOI: 10.2147/CBF.S66068

11 Aigner A, Brachmann P, Beyer J, Jager R, Raulais D, Vigny M, Neubauer A, Heidenreich A, Weinknecht S, Czubayko F and Zugmaier G: Marked increase of the growth factors pleiotrophin and fibroblast growth factor-2 in serum of testicular cancer patients. Ann Oncol 14(10): 1525-1529, 2003. PMID: 14504053 DOI: $10.1093 /$ annonc/mdg4 16

12 Souttou B, Juhl H, Hackenbruck J, Rockseisen M, Klomp HJ, Raulais D, Vigny M and Wellstein A: Relationship between serum concentrations of the growth factor pleiotrophin and pleiotrophin-positive tumors. J Natl Cancer Inst 90(19): 14681473, 1998. PMID: 9776412. DOI: 10.1093/jnci/90.19.1468

13 Jager R, List B, Knabbe C, Souttou B, Raulais D, Zeiler T, Wellstein A, Aigner A, Neubauer A and Zugmaier G: Serum levels of the angiogenic factor pleiotrophin in relation to disease stage in lung cancer patients. Br J Cancer 86(6): 858-863, 2002. PMID: 11953815. DOI: 10.1038/sj.bjc.6600202

14 Landriscina M, Cassano A, Ratto C, Longo R, Ippoliti M, Palazzotti B, Crucitti F and Barone C: Quantitative analysis of basic fibroblast growth factor and vascular endothelial growth factor in human colorectal cancer. Br J Cancer 78(6): 765-770, 1998. PMID: 9743297. DOI: 10.1038/bjc.1998.575

15 Madsen CV, Steffensen KD, Olsen DA, Waldstrom M, Sogaard $\mathrm{CH}$, Brandslund I and Jakobsen A: Serum platelet-derived growth factor and fibroblast growth factor in patients with benign and malignant ovarian tumors. Anticancer Res 32(9): 3817-3825, 2012. PMID: 22993324.

16 Keeley BR, Islami F, Pourshams A, Poustchi H, Pak JS, Brennan P, Khademi H, Genden EM, Abnet CC, Dawsey SM, Boffetta P, Malekzadeh R and Sikora AG: Prediagnostic serum levels of inflammatory biomarkers are correlated with future development of lung and esophageal cancer. Cancer Sci 105(9): 1205-1211, 2014. PMID: 25040886. DOI: $10.1111 /$ cas.12485

17 Palmer RD, Murray MJ, Saini HK, van Dongen S, AbreuGoodger C, Muralidhar B, Pett MR, Thornton CM, Nicholson JC, Enright AJ and Coleman N: Malignant germ cell tumors display common microrna profiles resulting in global changes in expression of messenger rna targets. Cancer Res 70(7): 29112923, 2010. PMID: 20332240. DOI: 10.1158/0008-5472.CAN09-3301

18 Gashaw I, Grummer R, Klein-Hitpass L, Dushaj O, Bergmann M, Brehm R, Grobholz R, Kliesch S, Neuvians TP, Schmid KW, von Ostau $\mathrm{C}$ and Winterhager $\mathrm{E}$ : Gene signatures of testicular seminoma with emphasis on expression of ets variant gene 4 . Cell Mol Life Sci 62(19-20): 2359-2368, 2005. PMID: 16158187. DOI: $10.1007 / \mathrm{s} 00018-005-5250-9$
19 Murray MJ, Halsall DJ, Hook CE, Williams DM, Nicholson JC and Coleman $\mathrm{N}$ : Identification of micrornas from the mir371 373 and mir-302 clusters as potential serum biomarkers of malignant germ cell tumors. Am J Clin Pathol 135(1): 119-125, 2011. PMID: 21173133. DOI: 10.1309/AJCPOE11KEYZCJHT

20 Korkola JE, Houldsworth J, Chadalavada RS, Olshen AB, Dobrzynski D, Reuter VE, Bosl GJ and Chaganti RS: Downregulation of stem cell genes, including those in a $200-\mathrm{kb}$ gene cluster at $12 \mathrm{p} 13.31$, is associated with in vivo differentiation of human male germ cell tumors. Cancer Res 66(2): 820-827, 2006. PMID: 16424014. DOI: 10.1158/0008-5472.CAN-05-2445

21 Kupershmidt I, Su QJ, Grewal A, Sundaresh S, Halperin I, Flynn J, Shekar M, Wang H, Park J, Cui W, Wall GD, Wisotzkey R, Alag S, Akhtari S and Ronaghi M: Ontology-based metaanalysis of global collections of high-throughput public data. PLoS One 5(9), 2010. PMID: 20927376. DOI: 10.1371/ journal.pone.0013066

22 de Souza MB, Curioni OA, Kanda JL and MB DEC: Serum and salivary macrophage migration inhibitory factor in patients with oral squamous cell carcinoma. Oncol Lett 8(5): 2267-2275, 2014. PMID: 25289107. DOI: 10.3892/ol.2014.2513

23 Kamel MM, Saad MF, Mahmoud AA, Edries AA and AbdelMoneim AS: Evaluation of serum pivka-ii and mif as diagnostic markers for hcv/hbv induced hepatocellular carcinoma. Microb Pathog 77: 31-35, 2014. PMID: 25448465. DOI: 10.1016/ j.micpath.2014.10.009

24 Fersching DM, Nagel D, Siegele B, Salat C, Heinemann V, Holdenrieder S and Stoetzer OJ: Apoptosis-related biomarkers sfas, mif, icam-1 and pai-1 in serum of breast cancer patients undergoing neoadjuvant chemotherapy. Anticancer Res 32(5): 2047-2058, 2012. PMID: 22593487.

25 Krockenberger M, Kranke P, Hausler S, Engel JB, Horn E, Nurnberger K, Wischhusen J, Dietl J and Honig A: Macrophage migration-inhibitory factor levels in serum of patients with ovarian cancer correlates with poor prognosis. Anticancer Res 32(12): 5233-5238, 2012. PMID: 23225421.

26 Zhang X, Weng W, Xu W, Wang Y, Yu W, Tang X, Ma L, Pan Q, Wang $J$ and Sun F: The association between the migration inhibitory factor $-173 \mathrm{~g} / \mathrm{c}$ polymorphism and cancer risk: A metaanalysis. Onco Targets Ther 8: 601-613, 2015. PMID: 25792844. DOI: $10.2147 /$ OTT.S72795 